УДК 392.8+641/642

DOI 10.25205/978-5-4437-1268-0-102-109

\title{
Ute Wallenböck
}

Masaryk University, Brno, Czech Republic

\section{CONNECTING FOODWAYS: CULTURAL ENTANGLEMENT IN INNER ASIA}

The paper deals with the cultural aspects of foods and beverages in Inner Asia with focus on the Tibetan cultural realm. I argue that everyday foods illustrate cultural identity: Food(s) are vehicles for expressing culture. In fact, food is the base of every society and food and at the same time it is a tool to communicate ideas, values, identities, and attitudes. Being aware that Tibetan cuisine represents a combination of influences from China, Central Asia, Mongolia, India, and Nepal, for instance, I am questioning according to what criteria do the Tibetans qualify a foodstuff or a dish as "traditional" or even "unique". I will, hence, validate the framework that food can produce control and coercion in both the political and social spheres.

Keywords: Tibetan food, Tibetans, Mongols, cultural entanglement

\section{Уте Валленбёк}

Масариков университет, Брно, Чехия

\section{СВЯЗЬ ГАСТРОНОМИЧЕСКИХ ТРАДИЦИЙ - СВИДЕТЕЛЬСТВО КУЛЬТУРНЫХ ПЕРЕСЕЧЕНИЙ ВО ВНУТРЕННЕЙ АЗИИ}

В работе представлены изыскания в области еды и напитков Внутренней Азии на примере Тибета. Мы оспариваем тезис, согласно которому еда является средством выражения культурных норм, а повседневные блюда демонстрируют этническую идентичность. Гастрономическая культура, безусловно, является основой любого общества и может быть использована как средство трансляции идей, ценностей, индивидуальности и отношений. Тем не менее, мы ставим под сомнение критерии, руководствуясь которыми тибетцы определяют свои блюда и продукты питания как «традиционные» и «уникальные», ведь тибетская кухня представляет собой комбинацию заимствований из Китая, Центральной Азии, Монголии, Индии и Непала. В работе также рассматривается вопрос, насколько еда может влиять на политическую и социальную стороны жизни общества.

Ключевые слова: Тибетская кухня, тибетцы, монголы, культурные пересечения

Food and cultures are inseparable. Food has been a manifestation of both the uniqueness and similarities of various cultures and societies in a global context. From the cultivation of ingredients, preparation of dishes, partaking of meals to handing down family recipes, the significance of food

(c) U. Wallenböck, 2021 
has been interwoven in the socio-economic and cultural fabrics of local and international scales. Moreover, it has to be kept in mind that societies all over the world are in continuous transformations. Hence, light will be shed on the various perspectives on how food, cultures and societies are interwoven. In fact, culinary culture is not a static phenomenon but cuisine and food-related costums are continually evolving. On the most elementary level, Inner Asian cuisines share ingredients and dishes. I state that the search for the authentic national cookery is an elusive un-realistic exercise. In fact, cultures evolve through contacts with other ethnic groups over times and consequently, cuisines change by the same process.

In regard to entanglements, I am looking at the cross-cultural connections in Inner Asia through the study of foodways, a collective term for cuisines and food rituals, with focus on Tibetan food(s).

Research on Asian and South Asian food became very popular in the past years, as well as on food of nomadic people such as the Mongols. However, it is quite surprising for me that there has been hardly any academic research done on Tibetan food(s) so far. The Tibetologist Petra Maurer [2011] gives a general overview of Tibetan food in a short non-academic article, and Diana Altner [2010] worked on fishery on the Tibetan plateau. Worth mentioning, is also Wu Qi's dissertation [2013. P. 44-59], in which he at least briefly addressed food in the Tibetan Amdo society and the changes of daily food(s) in modern history. Then there are also the various contributions in the trans-disciplinary journal Asian Highlands Perspectives (AHP) with its focus on the Tibetan Plateau. In some of the articles, in connection with rituals and festivals, food is described such as in Timothy Thurston and Tsering Samdrup's paper on Tibetan New Year in a Tibetan village in Amdo [2012]. However, the most recent research done on Tibetan food is by Geoffrey Barstow [2017] who focuses on the history of vegetarianism on the Tibetan plateau regarding Tibetan Buddhism. Moreover, as medicine and nutrition are closely related, the nutritious aspect of Sowa Rigpa (gsog ba rig pa), the Science of Healing, has to be mentioned. The rGyud bzhi, the four tantra of Sowa Rigpa, gives reference to Tibetan food - or at least its ingredients. The origins of the text are debated, but it seems to have been arranged in the form we know today in the twelfth century by the famous Tibetan physician, Yutog Yondan Gompo [gYu thog yon tan mgon po] (1112-1203). In chapter 16 of the second section of the four tantra, the "Explanatory Tantra", the six grains ( $\mathrm{bru}$ ) are listed, by being divided into leguminous crops (gang bu can), namely beans and peas, and crops (gra ma), such as rice, millet, wheat and different kinds of barley. In fact, this section also deals with dietetics by differentiating into food and beverages, whereas food is divided into five items, namely grain, meat, greens, butter with fats and food cooked. In terms of beverages, milk, water, chang (fermented grain) and others are explained [Ploberger, 2012. P. 231-248].

To my understanding, there is no explicit written material on food in historical Tibetan sources. Based on my current knowledge, not even cookbooks existed in the Tibetan cultural realm until the second half of the $20^{\text {th }}$ century.

"Most Tibetans learn to cook from an older person who is already a good cook, and they do not have exact, written, recipes to follow. Cooking is more a matter of experience and common sense, and getting a feeling how things go together and how they should taste and look!" [Rinjing Dorje, 1985. P. 50].

The first detailed account on Tibetan food (at least in a Western language) was written by Alexandra David-Neél, who went to Tibet in about 1916 as well as in 1924. In her book Gargantua au pays des neiges: Cuisine, traditions et images, she writes that Tibetans have no special cooking skills, and they always keep eating the same food. Differences only depend on the various soils on the Tibetan plateau. In her book she describes the preparation of beverages, foods made from grain, meat, dishes made from meat, milk products such as yoghurt, butter and cheese. Then, there is the section of soups - among one of the soups is called “Mongol broth" [David-Neél, 1976. P. 76], implication the cultural exchange between Mongols and Tibetans even in terms of food. 
The Tibetan cultural realm is a huge tract of land, and the different regions of the Tibet have varying climate. And additionally, the Tibetan plateau hosts enormously varying physical environments: From southeast to northwest of Tibet, montane forests, alpine meadows, alpine grasslands or steppes, semi-deserts are distributed. Consequently, affected by the alpine altitude and harsh environment, Tibetans have their featured food species and unique dining habits.

Hence, I argue that there is Tibetan regional food as well as the various foods also depend on the lifestyle. Consequently, the so-called traditional dished depend on the region as well as on the lifestyle.

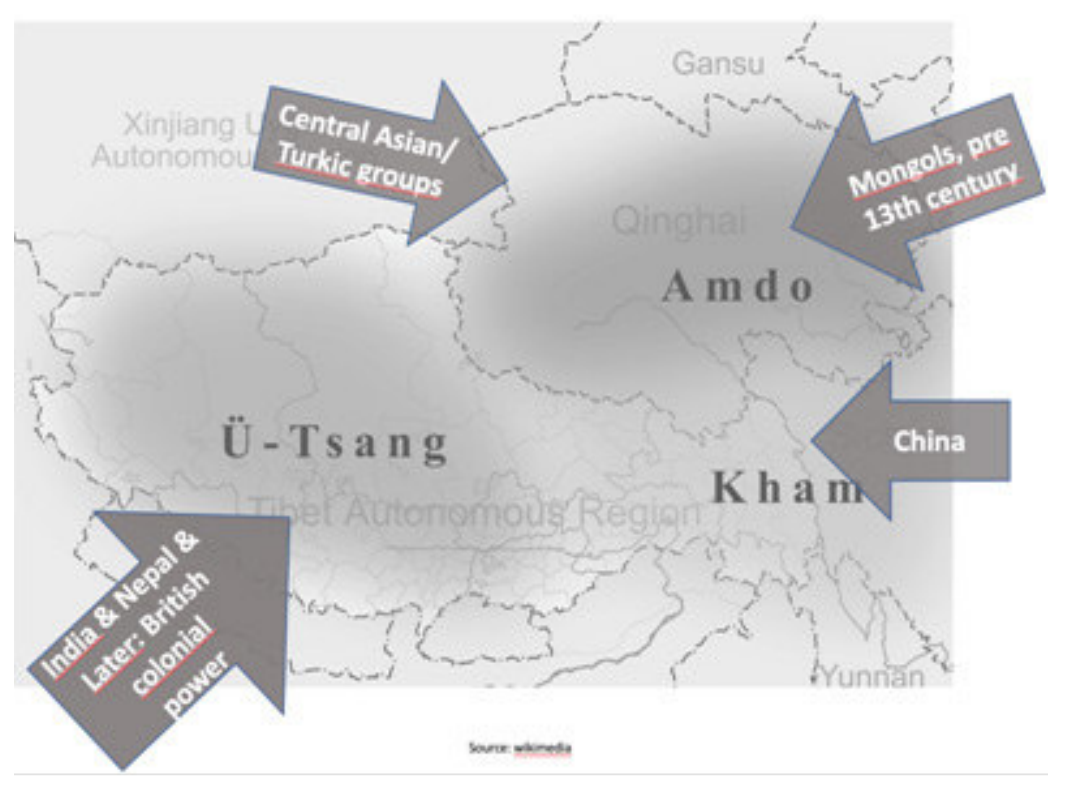

Fig. 1

In terms of regions, reference shall be given to the the three "traditional" Tibetan provinces of Amdo, Kham and ÜTsang, whereas the latter refers to contemporary Tibet autonomous region with Lhasa as its capital (fig. 1). In ÜTsang, Indian, Nepali and British (because of colonialism) cultural traces can be found. The region of Kham covers parts of contemporary Yunnan and Sichuan, as well as small parts of Qinghai and the Tibetan autonomous regions (TAR). In these regions, preliminary contacts with Chinese culture and other ethnic groups can be traced. Interesting for my research is Amdo, which is concentrated in today's China's province of Qinghai, and also includes parts of Gansu and Sichuan. In Amdo, there has been a great influence and contribution of Turkic (Muslim), Chinese, and Mongol cultures. Matthias Hermanns who lived in Amdo during the Republican time - reports in his book "The Family of Amdo Tibetans" [1959, P. 134] that during festivals, Chinese dishes were served. And in his book on "Nomads in Tibet" [1949. P. 59], he states that Tibetans sometimes use Chinese spices for their dishes. Hence, the Chinese influence on food in that area can be seen. Influence of the Chinese cultural realm is visible all over the Tibetan areas, and as Matthew Kapstein [2006. P. 56] has already drawn attention to the fact that "sons of noble families were sent to China to study the classics, and Chinese scholars were invited to Tibet to handle official correspondence with the Tang court".

Due to lack of research on Tibetan food from the various aspects, in my on-going research, I hence want to understand, not only how Tibetan food is produced, distributed, and consumed in all of its many forms, but I am also questioning the existence of "traditional” Tibetan food in the context of Inner Asia with emphasis on the cultural entanglements in terms of food.

There is a long-lasting debate in the humanities and cultural studies on how to conceptualize the processes of change affected through culture contact [Barnard et al, 1996]. In order to understand local cultures, one has to look at the processes of intercultural encounters, assimilation and synthesis, based on the awareness that cultures are highly interwoven, interdependent, and constituted in processes of contact and exchange. Thus, issues of "acculturation" or "hybridity" [Werbner et al, 1993; Burke, 2009; Welsch, 2011], which have gained a certain popularity in cultural studies in the age of globalization, are no newcomers on the agenda in Inner Asian studies. The focus on matters of transmission as social and cultural process inevitably lead to a greater awareness of how cultures are 
highly interwoven and interdependent. Studies dealing with the issue of cultural transfers have highlighted the many ways in which these may occur [Burke, 2009; Viebeck, 2017]. Hence, when looking at Tibetans and their history, they have also become subjected to a range of influences and changes in their everyday lives, including food and eating habits. They have been entangled in networks of relations, all of which shape their foods. Due to various impacts of cultural transfer as well as cultural exchange, products from other cultural realms were imported, borrowed, and then integrated/incorporated. In terms of the Tibetan cultural realm, the cultural influences in Tibet especially from Turkic and Mongol group traces back to the period of the Mongol empire as well there has been considerable contact between the Mongols and Tibetans already before 1240 [Atwood, 2015]. Consequently, I argue that based upon these contacts, there is close relation between Tibetan and Mongol food. Many Tibetan dishes might be a borrowing from the various neighboring cultural realms. Therefore, I argue that on one hand, Tibetans are using traditional recipes using more or less traditional ingredients, and on the other hand they use "other" recipes cooked with Tibetan taste, namely with ingredients preferred by Tibetans.

The most valuable source on Mongol food dates back to the $14^{\text {th }}$ century, namely the Yinshan zhengyao (YSZY) 飲膳正要, or “Proper and Essential Things for the Emperor's Food and Drink” written by $\mathrm{Hu}$ Sihui 忽思慧 in 1330. The text includes specific culinary recipes (mainly non-Chinese ones), focuses on the medical aspects of nutrition and the medical values of food and recipes. $\mathrm{Hu}$ presents the cuisine of a world empire, one standing at the crossroads of the many different cultures finding expression within it: Mongol, Turkic, South and West Asian, as well as Chinese. But not reference to Tibetan. In fact, Hu's text shows the culinary results of long-term mutual contacts between the various peoples of Inner Asia. Moreover, when consulting Hu's text, it can be seen that the various cuisines are distinctive from each other due to climate, resources, geography, history, and lifestyle. Additionally, to the increasing cross-border behavior and the subsequent cultural interactions dishes as well as flavoring have been borrowed, then adapted. Boundaries are elaborated in the process of producing, procuring, preparing, and consuming of food, and cuisines do not develop within a single region, but instead come about through exchange and borrowing. By borrowing new foods and spices, some native food has been adapted or even transformed into new dishes throughout the centuries. Of key importance for the Mongols were the borrowings from a variety of other cultures - besides the Chinese and Turkic ones, also Siberian and Central Asian. According to Buell and Anderson, "the ancestors of the later Altaic people would have been involved in mediating any exchanges that did occur." [Buell and Anderson, 2010. P. 51]. Moreover, since the text is riddled with transcriptions of foreign words, it can be stated that the cuisine during the Yuan dynasty has been influenced by Turkish-Mongol and Arab-Persian cuisine: "It may even be argued that the many ... recipes, are Mongolian in essence, but cooked with Muslim spices and additions, sometimes in a Chinese way. The dishes are artificial and the result of a conscious attempt on the part of the Mongols to create a new international cuisine" [Buell and Anderson, 2010. P. 88]. In fact, Hu's text incorporates foods from all the realms conquered or even affected by the Mongols. Hu presents the cuisine of a world empire, one standing at the crossroads of the many different cultures finding expression within it: Mongol, Turkic, South and West Asian, Chinese. The cuisine of the Mongol empire already included highly acculturated dishes, especially among the Mongolian court elites after the $14^{\text {th }}$ century. "The court food described ... represents a peak of westward influence, but not a sudden intrusion of a totally new cuisine“ [Buell and Anderson, 2010. P 56]. Hu's text shows the culinary results of long-term mutual contacts between the various peoples of Inner Asia, such as the Turkic groups and Mongols. However, the main difference between the Chinese, Turkish and Mongolian cooking was the popularity of milk products - as among the Mongol elites, vast amounts of dairy products were consumed.

Besides Hu's text, there are also several accounts by European missionaries, merchants and adventurer of the $13^{\text {th }}$ and $14^{\text {th }}$ century, who give report on food and beverages at the Mongol court as well 
as within the Mongol empire. The Flemish Franciscan missionary William of Rubruck (1248-1255) for instance writes: "And we found him [Möngke] with a few members of his household drinking liquid tam, that is a food made from dough, for the comfort of his head" [Dawson, 1955. P. 168]. I assume that this kind of food had spread from Tibet to the Mongols by the mid-thirteenth century. The dish Rubruck is talking about is assumingly tsampa, the most common staple foodstuff in Tibet, made from roasted barley. There are several ways of the preparation of this dish, mainly "after being thoroughly kneaded with the fingers in a mixture of tea and butter, is taken out in lumps and eaten from the hand" [Rijnhart, 1901. P. 47].

By taking food as an identity marker as an example, in this paper, I will shed light on the food produced and consumed in contemporary Henan Mongol Autonomous County in Qinghai province, in the PRC, inhabited mainly by Tibetans and Mongols. Due to the long-term mutual contacts between Tibetans and Mongols, a milieu was created in which unique local customs, language patterns, and social communities have emerged; the origins of which lie in encounters between Tibetan and Mongol cultures that share certain features to form a new, distinct culture [Wallenböck, 2019]. In fact, in course of my fieldwork in 2014 and 2017 and in-depth reading of primary sources, I came across food as an identity marker, especially for the Mongols of contemporary Henan County to distinct themselves from the Tibetans. As an example, during an interview one informant told me, I quote:

We are not really Mongols. We do not speak Mongolian but Tibetan. Now we eat tsampa like the Tibetans even though we used to refer to it as "torma tsampa" 1

Based on the argument from my informant, I did some literature research and came across a historical source of the Qing Dynasty. Besides other issues, Zhongyou Angqing Jiabu elaborates that tsampa, the staple food of the Tibetans, was unknown to the Mongols as a food because it was only known as “torma tsampa” (duoma fen 朵马粉). In his book, Zhongyou Angqing Jiabu [2008. P. 138] wrote that the eating and living habits as well as the clothing of the Mongols of the Henan grasslands were very strongly influenced by the Tibetan environment. He states - as well as it is written in the Annals of Henan County [2010. P. 377] - that millet has been the main food (in Chinese xiaomi 小 米 and in Tibetan called ti er mu wu da 铁尔木吾达 (Tib. ther mi bu ta)). Much to my surprise, hardly any millet can be found in that area nowadays.

In history, Mongols as well as most nomadic peoples of Inner Asia obtained most of their food from animals. The Franciscan monk John of Plano Carpini, who was sent as envoy of Pope Innocent IV to the Mongols in the 1240 s, reports as following:

[The Mongols] have neither bread nor herbs nor vegetables nor anything else, nothing but meat... They drink mare's milk in very great quantities if they have it; they also drink the milk of ewes, cows, goats and even camels. [Carpini, 1955. P. 16-17].

Another milk product worth mentioning is a beverage famous among the Mongols but unknown among Tibetans - kumiss, fermented mare milk. Kumiss is the Russian term for the Mongolian airag. William of Rubruck, Marco Polo, and Ibn Battuta record that kumiss was served important ceremonial function. [Smith, 2000] Moreover, the strict protocol accompanying the serving and consumption of kumiss is recorded in The Secret History of the Mongols. Matthias Hermanns [1949. P. 66-79] gives a detailed account of almost five pages on airag in regard to the various Mongol groups and the people of the Altai, and the difference to chang, an alcoholic drink that is made of barley, rice or millet, among Tibetans. Susie Rijnhart [1901. P. 223] in contrary reports after having arrived west of Kokonor (Qinghai Lake) as follwoing: "The food of the Mongols here is the same as that of the Tibetans, and like the latter they make wine, and also a sort of koumiss from mare's milk."

${ }^{1}$ Torma (gtor $\mathrm{ma}$ ) are sculptures mostly made of butter, clay or tsampa (rtsam pa), which symbolize, among other things, food for the gods. 
Back to the Mongols of Henan County. According to the local source written by Dkon mchog skyab [2009], kumiss was only drunk by the local rulers at celebrations, but not by the "normal" population. Additionally, in the Annals of Henan, reference is only given to mare milk (manai 马奶) as well as sheep milk (yangnai 羊奶) being drunk until the end of the Republican era. Interestingly, no reference at all is given if the milk was drunk fermented or fresh.

In terms of dairy products, they are perceived as "white food" (dkar zas), with the meaning that white food is any food uncontaminated by blood, free from killing, such as milk, butter, cheese, and yogurt. Thus, after milk, the next "white food" worth mentioning is butter. Zhongyou Angqing Jiabu [2008. P. 137] states that the Mongols did not know butter, and only in later years/centuries they learned the technology of making butter. However, this is in contradiction with Rubruk's travel report in which he describes that one of the dishes he ate was made of millet with butter [Rubruck, 2013. P. 151]. But again, interestingly, the information given in the Annals of Henan is in line with Zhongyou Angqing Jiabu, that historically, the Mongols of Qinghai did not make nor eat butter. Therefore, at least in regard to the Mongols in Qinghai, it can be stated that butter is surpassingly another "typical” Tibetan food. Sven Hedin (1865-1952), a Swedish explorer who led various expedition through Central and Inner Asia, states that he has never tasted anything as good as Tibetan yoghurt; for him compared to Tibetan yoghurt "oysters and champagne are simply humbug!" [Hedin, 2008. P. 236].

Besides the "white foods", are also the "red foods" (dmar zas), which include meat and blood. The Mongols' main meat foods were mutton. According to Zhongyou Angqing Jiabu as well as to the Annals of Henan [2010. P. 377] meat and milk are counted as the main stable food for the population of the area of the Henan grasslands. According to the Annals of Henan, besides beef and mutton, camel meat was eaten. In the various interviews I was told that Mongols used to eat meat of sheep, camels, yaks and even marmots, but not of horses or pork. Interestingly, in terms of Tibetans, according to Ekai Kawaguchi [1909. P. 269], who went to Tibet for five years in 1900, reports that also pork is eaten, but only by the Tibetans who have dealings with the Chinese. My interviewees highlighted that the eating of camel meat and marmot meat was making them distinct from the Tibetans. This refers only to the past, as in the present, there are no more camels in Henan County.

Regarding the consumption of meat, meat is eaten half-cooked, or in Western culinary terms "rosé rare", or air-dried among Tibetans and Mongols. According to Alexandra David-Neél [1953], the smell of roasted meat is not appreciated by the gods, as well as Kawaguchi [1909. P. 265] mentioned that "meat is regarded as unceremonial" — that's why Tibetans do not roast meat.

Naturally dried meat is often referred to as "typical" Tibetan food in Western society. But as a matter of fact, it has to be kept in mind that the technique of air drying might have been borrowed from the Mongols. Therefore, the air-dried meat can be taken as an example that food(s) are the result of an evolution through cultural transfer. Dried meat products have the advantage that they can be preserved under ambient conditions as well as they require little storage.

Another dish worth investigating is pasta. According to historical sources, grain and noodle dishes find their origin in the Turkic Middle East [Buell, 2010. P. 117], hence, they are of non-Chinese origin. The Jesuit Ippolito Desideri of the early $18^{\text {th }}$ century mentions thukpa, in a noodle soup which originated from Eastern Tibet, Amdo. According to Desideri [2010. P. 270], thukpa "is a kind of watery vegetable broth into which they add while it's boiling, a little at a time, roasted barley flour and chura (Cciurà), a kind of grated cheese”.

In fact, the dish described by Desideri seems not be a noodle-dish. However, by looking at Western travel reports, in regard to pasta or noodles, the Lazarist missionaries Huc and Gabet who traveled to Tibet in 1844-1856, mention "pasta"; and Susie Carson Rijnhart [1901. P. 38] reports about " $m$ 'ien", with the additional information that "[i]nstead of cutting it into strips he [the cook] would cut it into squares". All these reports refer to the Tibetan cultural realm of Amdo, an area which had historically closer economic relations to the various courts of China than to Lhasa. In regard 
to China, the French sinologist Françoise Sabban together with Silvano Serventi [2002] conducted research on pasta in China; they trace back the origin of noodles in the kingdom of Wei in Shanxi around $281 \mathrm{~A}$. D. They postulate that during that time, noodles were known with the Chinese term "bing", a generic term for all dishes made with kneaded wheat flour. Then, with the Tang dynasty, the term "mian" for wheat flour appears in sources. And only with the Mongols, beginning in the $10^{\text {th }}$ century, pasta became a more refined foodstuff. Based on these findings, I assume that any of the dishes made of wheat flour eaten in Tibet, has been imported by the Mongols or by the Chinese.

By having given some examples on the different foods of Mongols and Tibetans, it is evident that the food cultures in this area have mixed and complemented each other over the centuries, and at the same time, the various cultures demand food(s) and foodstuff to "belong" to the cultural identity of their ethnic group. Therefore, I argue that food can be viewed as a marker of ethnic identity. Despite the matter of fact, that the various "traditional" foods of Tibet have developed in course of the cultural exchange and entanglement with the neighboring countries, they still perceive "their" food as unique and traditional.

\section{References}

Altner Diana. From Water Radish to Fish Restaurant: Recent Development of Fisheries in Central Tibet //AAS Working Papers in Social Anthropology, 2010. Vol. 18. P. 1-13.

Atwood Christopher P. The First Mongol Contacts with the Tibetans // R. Vitali (Ed.), Trails of the Tibetan Tradition: Papers for Elliot Sperling). Paris: UMR 8155 (CRCAO) of The French National Center for Scientific Research (CRNS), 2015. P. 21-45.

Barnard Alan and Jonathan Spencer, (eds). Encyclopaedia of Social and Cultural Anthropology, London 1996.

Barstow Geoffrey. Food of Sinful Demons: Meat, Vegetarianism, and the Limits of Buddhism in Tibet. University of California Press, 2017.

Bentley Jerry H. Old World Encounters: Cross-cultural Contacts and Exchange in Pre-modern Times, New York 1993.

Buell Paul and Eugene Anderson. A Soup for the Qan: Chinese Dietary Medicine of the Mongol Era As Seen in Hu Sihui’s Yinshan Zhengyao. Brill, 2010.

Burke Peter. Cultural Hybridity, Cambridge 2009.

John of Piano Carpini. History of the Mongols // Christopher Dawson,The Mongol Mission, London: Sheed and Ward, 1955.

David-Neél Alexandra. Im Schatten des Himalaja: Zauber und Wunder in Nepal. Brockhaus, 1953.

David-Neél Alexandra. Leben in Tibet. Kulinarische und andere Traditionen aus dem Lande des Ewigen Schnees, Basel, 1976.

Dawson Christopher (Ed.). Mission to Asia. Harper Torchbook, 1955. Original text: Wyngaert, Anastasius vand er. Sinica franciscana. Vol. I, Itinera et relationes fratrum minorum saeculi XIII et XIV, Quaracchi-Firenze: Ad Claras Aquas,1929.

Desideri Ippolito. Leonard Zwilling (ed.) and Michael J. Sweet (translator), Mission to Tibet: The Extraordinary Eighteenth-Century Account of Father Ippolito Desideri S. J., Wisdom publication, 2010.

Dkon mchog skyab. 2009. rMa lho sog zhog gi lo rgyus rgyu cha phyogs bsgrigs (A Compilation of Henan Mongol Historical Materials). 6/6 Bd. [China].

Hedin Sven. Abenteuer in Tibet. 1899-1902. Stuttgart: Edition Erdmann, 2008.

Hermann Matthias. Die Nomaden von Tibet: die sozial-wirtschaftlichen Grundlagen der Hirtenkulturen in A mdo und von Innerasien, Ursprung und Entwicklung der Viehzucht. Wien: Herold Verlag, 1949. 
Hermanns Matthias. Die Familie der A mdo-Tibeter. München: Verlag Karl Alber, 1959.

Hu Sihui 忽思慧. Yinshan zhengyao (YSZY) 飲膳正要 [Proper and Essential Things for the Emperor's Food and Drink], ca. 1330. https://ctext.org/wiki.pl?if=gb\&res=968624

Huc Régis-Everiste. Travels in Tartary, Thibet and China during the years 1844-56. Chicago: The Open Court Pub. Co, 1900. https://www.gutenberg.org/files/32747/32747-h/32747-h.htm

Kapstein Mathew. The Tibetans, Blackwell Publishing, Malden- Oxford-Victoria 2006.

Kawaguchi Ekai. Three years in Tibet. Theosophical Publishing Society, Benares and London, 1909.

Maurer Petra. Die traditionelle Ernährung der Tibeter // Akademie Aktuell. Zeitschrift der bayrischen Akademie der Wissenschaften. Heft 36, Schwerpunkt Ernährung. Grundlagen des Lebens, Ursache von Krankheit, Ausdruck von Kultur und Religion, 2011. P. 35-39.

Ploberger Florian. Wurzeltantra und Tantra der Erklärungen aus: Die vier Tantra der Tibetischen Medizin. Bacopa Verlag, 2012.

Rachewiltz Igor de. The Secret History of the Mongols. A Mongolian Epic Chronicle of the Thirteenth Century. Shorter version edited by John C. Street, University of Wisconsin - Madison. Books and Monographs. Book 4, 2015. http://cedar.wwu.edu/cedarbooks/4

Rijnhart Susie Carson. With the Tibetans in Tent and Temple. Chicago, New York \& Toronto: Fleming H. Revell Company, 1901.

Rinjing Dorje. Food in Tibetan Life. Prospect Books, 1985.

Rubruk Wilhelm von. Reise zu den Mongolen. Von Konstantinopel nach Karakorum. Herausgegeben von Hans Dieter Leicht. Edition Erdmann, 2013.

Serventi Silvano and Sabban Françoise. Pasta. The Story of a Universal Food. New York Chichester, West Sussex: Columbia University Press, 2002.

Smith John M. Dietary Decadence and Dynastic Decline in the Mongol Empire // Journal of Asian History, 34/1, 2000.

http://afe.easia.columbia.edu/mongols/pastoral/masson_smith.pdf

Thurston Timothy and Tsering Samdrup. An A mdo Tibetan Pastoralist Family's Lo sar in Stong skor Village // Asian Highlands Perspectives, 2012. Vol. 21. P. 33-69.

Viehbeck Markus (ed.). Transcultural Encounters in the Himalayan Borderlands. Kalimpong as a "Contact Zone," Heidelberg, 2017.

Wallenböck Ute. Die Bevölkerung am Sino-Tibetischen Grenzgebiet. Identitätskonstruktion der Tibet- Mongolen. (Globalgeschichte und Global Studies, Vol. 1), Münster: Aschendorff Verlag, 2019.

Welsch Wolfgang. Immer nur der Mensch? Entwürfe zu einer anderen Anthropologie. Berlin, 2011.

Werbner Pnina and Tariq Modood (eds.). Debating Cultural Hybridity. Multi-cultural Identities and the Politics of Anti-racism, London, 1997.

Wu Qi. Tradition and modernity: cultural continuum and transition among Tibetans in Amdo. Dissertation. University of Helsinki, 2013.

(Qing) Zhongyou Angqing Jiabu (清) 仲优·昂青嘉布. Xian zu yan jiao 先祖言教 (Original title in Tibetan: Deb thar [sic!] mes po'i shal lung). Xining: Qinghai Renmin Chubanshe, 2008.

Zhuocang Cairang 卓仓才让. Huang He Nan Menggu zhi 黄河南蒙古志 (Annals of Henan). Lanzhou: Gansu Minzu Chubanshe, 2010. 